\title{
Pengelolaan Perpustakaan Sekolah di MTs Negeri 7 Kebumen
}

\author{
Rohmy Afriatin*, Danusiri \\ Universitas Islam Negeri Walisongo, Semarang, Indonesia
}

\begin{abstract}
ABSTRAK
Penelitian ini bertujuan untuk mendiskripsikan pengelolaan perpustakaan sekolah di MTs Negeri 7 Kebumen. Pengelolaan tersebut meliputi aspek perencanaan, pengorganisasian, pelaksanaan atau penyelenggaraan, evaluasi, dan kendala di perpustakaan. Jenis penelitian ini adalah kualitatif lapangan (field research) yang dilakukan langsung di medan terjadinya gejala-gejala yang diteliti yaitu MTs Negeri 7 Kebumen. Pendekatan yang digunakan adalah kualitatif deskriptif di mana hasil penelitiannya berbentuk deskripsi kata-kata. Penelitian ini dilakukan secara intensif, yakni peneliti ikut berpatisipasi selama di lapangan. Pengumpulan data penelitian ini menggunakan dokumentasi, observasi dan wawancara, setelah data terkumpul kemudian dianalisis dan dinyatakan dalam keadaan sewajarnya atau sebagaimana adanya tanpa mengubahnya menjadi angka atau simbol. Hasil penelitian menunjukkan bahwa pengelolaan perpustakaan sekolah di MTs Negeri 7 Kebumen menunjukan sebagai berikut: (1) dalam hal perencanaan sudah cukup baik dan sudah direncanakan sesuai dengan tujuan maupun dengan visi dan misi walaupun ada beberapa kendala salah satunya adalah dalam hal ruangan, (2) pengorganisasian sudah baik dan berjalan secara terstruktur, (3) pelaksanaan maupun penyelenggaraan cukup baik, (4) evaluasinya berjalan dengan baik karena dilaksanakan setiap hari, (5) kendala yang dihadapi dalam pengelolaan perpustakaan adalah mengenai ruangan yang belum memenuhi standar, sarana dan prasarana kurang mencukupi, pengadaan bahan koleksi kurang maksimal dan tidak ada pelatihan khusus bagi staf perpustakaan.
\end{abstract}

Kata kunci: manajemen perpustakaan; perpustakaan sekolah; organisasi perpustakaan

\begin{abstract}
This study aims to describe of school library management at MTs Negeri 7 Kebumen which includes aspects; (1) planning, (2) organizing, (3) implementing (4) evaluating, and (5) what problems are in the library. This type of research is qualitative field (field research) which is carried out directly in MTs Negeri 7 Kebumen. While the approach used is descriptive qualitative. This research was conducted intensively, in which researchers participated in the field. This research data collection using documentation, observation and interviews. After the data has been collected, it is analyzed and stated in a state that is reasonable or as it is without converting it into numbers or symbols. Based on the results of the research, in describing the management of the school library at MTs Negeri 7 Kebumen, it shows the following, (1) in terms of planning it is good enough and has been planned according to the objectives and vision and mission although there are several obstacles, one of which is in terms of space, (2) the organization is good and running in a structured manner, (3) the implementation and implementation is quite good, (4) the evaluation is running well because it is carried out every day, (5) the obstacles faced in library management are regarding rooms that do not meet standards, facilities and inadequate infrastructure, procurement of collection materials is not optimal and there is no special training for librarians.
\end{abstract}

Keywords: library management; school library; library organization

\section{PENDAHULUAN}

Perpustakaan sekolah sebagai salah satu sarana pendidikan penunjang kegiatan belajar siswa memegang peran yang sangat penting dalam memacu tercapainya tujuan pendidikan di sekolah atau madrasah. Lebih-lebih jika kita lihat perkembangan ilmu pengetahuan dan teknologi sekarang ini sedemikian pesatnya, maka peranan buku sebagai sumber informasi sangat kuat dan mutlak diperlukan di sekolah-sekolah. Darmono menjelaskan bahwa perpustakaan sekolah atau madrasah sabagai ilmu pengetahuan berperan sangat penting dalam meningkatakan kecerdasan

\footnotetext{
* Corresponding Author.

Email address. rohmyafriatin@gmail.com (R. Afriatin)
} 
dan meningkatkan pengetahuan para siswa. ${ }^{1}$ Perpustakaan sekolah atau madrasah harus bisa memainkan peran, khususnya dalam membantu siswa untuk mencapai tujuan pendidikan. Berkaitan dengan perlunya perpustakaan sekolah untuk mendukung pelaksanaan pendidikan juga terdapat dalam standar nasional pendidikan dalam bagian 11 tentang Tenaga Kependidikan pasal 35 ayat 1 . Pada pasal ini dinyatakan bahwa perlunya tenaga perpustakaan untuk semua jenjang pendidikan mulai jenjang SD/MI, SMP/MTs, SMA/MA, SMK/MAK, SDLB, SMPLB, SMALB, Paket A, Paket B, Paket C, dan lembaga khusus dan keterampilan.

Darmanto menjelaskan bahwa hakikat perpustakaan sekolah atau madrasah adalah pusat sumber belajar dan sumber informasi belajar bagi warga sekolah. Jika dikaitkan dengan proses belajar mengajar di sekolah, perpustakaan memberikan sumbangan yang sangat berharga dalam upaya meningkatkan aktivitas siswa serta meningkatkan kualitas pendidikan dan pengajaran. ${ }^{2}$ Melalui penyediaan perpustakaan, siswa dapat berintraksi dan terlibat langsung baik secara fisik maupun mental dalam proses belajar. Perpustakaan sekolah merupakan bagian integral dari program sekolah secara keseluruhan. Perpustakaan bersama-sama dengan komponen pendidikan lainnya turut menentukan keberhasilan proses pendidikan dan pengajaran. Melalui perpustakaan, siswa juga dapat mendidik dirinya secara berkesinambungan.

RUU perpustakaan pada Bab 1 pasal 1 menyatakan bahwa perpustakaan adalah institusi yang mengumpulkan pengetahuan tercetak dan terekam yang dikelola dengan cara khusus guna memenuhi kebutuhan intelektualitas para penggunaanya melalui beragam cara intraksi pengetahuan. Perpustakaaan merupakan salah satu unit yang memberikan layanan kepada peserta didik, dengan maksud membantu dan menunjang proses pembelajaran di sekolah, melayani informasi-informasi yang dibutuhkan serta memberi layanan rekreatif melalui koleksi bahan pustaka.

Lasa menjelaskan perpustakaan sebagai lembaga pendidikan dari lembaga informasi akan memiliki kerja yang baik apabila ditunjang dengan pengelolaan yang memadai. Dengan adanya sebuah pengelolaan, seluruh aktifias lembaga akan mengarah pada upaya pencapaian tujuan yang telah ditetapkan, sehingga seluruh elemen dalam suatu lembaga tersebut akan berusaha memfungsikan dari menyesuaikan dengan ketentuan lembaga ataupun perpustakaan. ${ }^{3}$ Oleh sebab itu, perpustakaan sekolah atau madrasah harus benar-benar dapat dikelola dengan baik sesuai dengan manajemen pengelolaan perpustakaan sekolah, karena hal itu sangat penting bagi penyelenggaraan perpustakaan maupun sekolah.

Darmono menerangkan bahwa pengelolaan perpustakaan adalah kegiatan untuk mempersiapkan bahan pustaka dengan suatu sistem, agar mudah, cepat, dan akurat dalam mencari bahan pustaka yang diperlukan. Pengelolaan perpustakaan akan menentukan sejauh mana perpustakaan sekolah dapat berjalan dengan baik dan mendukung proses pembelajaran yang inovatif di sekolah. Pengelolaan perpustakaan diperlukan untuk mengetahui sebuah perpustakaan dapat berfungsi dengan baik, dan tata kelola perpustakaan banyak menentukan keberhasilan dari sebuah perpustakaan. ${ }^{4}$ Bahan pustaka, ruangan, dan perlengkapan lainnya juga berpengaruh dalam keberhasilan penyelenggaraan perpustakaan di sekolah, walaupun ruangannya yang tersedia lengkap semuanya tetapi kurang berguna apabila tidak ditata atau dikelolah dengan baik, dan kebanyakan perpustakaan di sekolah sekarang ini dianggap hanya sebagai gudang buku, belum difungsikan secara optimal sebagai pusat sumber belajar. Dalam pengelolaan perpustakaan di sekolah sehari-hari perlu adanya satu orang atau lebih yang ditunjuk untuk mengelola perpustakaan dengan baik. Orang-orang yang ditunjuk harus memiliki tanggung jawab dalam manajemen dan kecakapan mengelola perpustakaan sekolah. Besar kecilnya hasil yang telah dicapai oleh adanya penyelenggaraan perpustakaan bergantung oleh pengelolanya, dan manajemen merupakan kendala utama dalam menyelenggarakan dan

\footnotetext{
${ }^{1}$ Darmono, Perpustakaan Sekolah: Pendekatan Aspek Manajemen dan TataKerja (Jakarta: Grasindo, 2001). hlm.3.

${ }^{2}$ Sudirman Anwar, Said Maskur, dan Muhammad Jailani, Manajemen Perpustakaan (Riau: Indragiri, 2019). hlm.7.

${ }^{3}$ Lasa Hs., Manajemen Perpustakaan (Yogyakarta: Pinus, 2009). hlm.1.

${ }^{4}$ Darmono, Perpustakaan Sekolah: Pendekatan Aspek Manajemen dan TataKerja. hlm.3.
} 
mengembangkan sebuah perpustakaan, karena sekolah menunjuk petugas yang tidak memiliki latar belakang kepustakawanan sehingga belum pawai dalam mengelola perpustakaan.

Anwar menerangkan apalagi adanya perpustakaan di sekolah harus berjalan dengan efektif dan mampu mendukung kurikulum dan program-program sekolah. Untuk menunjukan pengelolaan perpustakaan yang baik, maka pengelola perpustakaan perlu mengembangkan kemampuan profesional petugasnya sebagai pustakawan, memperhatikan kemampuan yang diperlukan dan prosedur yang dibutuhkan untuk dapat mengelola perpustakaan secara efektif, dapat mengembangkan kebijakan dan prosedur dengan prinsip-prinsip yang mengaktualisasikan visi dari perpustakaan, memperlihatkan keterkaitan antara sumber-sumber informasi dan tujuan dan prioritas sekolah serta menunjukan peran guru-pustakawan melalui rencana perpustakaan. ${ }^{5}$ Salah satu sekolah yang telah memiliki perpustakaan dan ingin mengembangkan sumberdaya manusia dan menejemen perpustakaan yang baik adalah Madrasah Tsanawiyah (MTs) Negeri 7 Kebumen.

MTs Negeri 7 Kebumen merupakan lembaga pendidikan yang terletak di Komplek Kauman Prembun, Desa Bagung, Kecamatan Prembun, Kabupaten Kebumen. Madrasah tersebut merupakan salah satu madrasah yang berada di Kecamatan Prembun yang dulu bernama MTs Negeri Prembun. MTs Negeri 7 Prembun sebagai lembaga pendidikan tentu memiliki sarana dan prasarana guna menunjang pendidikan dan pengajaran, salah satu penunjangnya adalah perpustakaan. Perpustakaan MTs Negeri 7 Kebumen merupakan wadah informasi bagi peserta didik, pendidik, maupun tenaga pendidik di lingkungan sekolah. Untuk lebih mengoptimalkan fungsinya sebagai sumber informasi, pihak dari sekolah maupun pengelola perpustakaan sangat berharap akan terciptanya perpustakaan yang dikelola dengan baik sehingga perpustakaan MTs Negeri 7 Prembun dapat memenuhi kebutuhan civitas sekolah dengan baik pula.

Pengelolaan perpustakaan akan berhasil sesuai dengan tujuan yang sudah ditentukan. Perpustakan sekolah harus dikelola oleh orang-orang yang memiliki keahlian dalam mengelola perpustakaan sekolah yakni pustakawan atau petugas yang sudah mengikuti diklat kepustakawanan. Petugas perpustakaan di MTs Negeri 7 Kebumen ada tiga orang, satu berperan sebagai kepala perpustakaan dan dua orang sebagai stafnya. Petugas perpustakaan tersebut dituntut untuk mampu mengelola perpustakaan sekolah agar perpustakaan tersebut dapat melayani pemustaka secara profesional.

Berdasarkan observasi kondisi perpustakaan di MTs Negeri 7 Kebumen, proses pengelolaan perpustakaan masih kurang maksimal. Hal ini bisa dilihat dari pengadaan koleksi perpustakaan sekolah MTs Negeri 7 Kebumen, perpustakaan tersebut memiliki koleksi buku paket pelajaran, namun belum memenuhi jumlah siswa, padahal perpustakaaan sekolah harus menyediakaan buku-buku yang lengkap, karena koleksi menjadi sangat penting bagi guru dan siswa terkait dengan keperluan peningkatan kegiatan belajar dan mengajar. Dalam hal proses shelving (penataan buku) juga berjalan kurang baik, ada beberapa buku di rak yang tidak sesuai peletakannya dengan jenis bukunya serta masih ada buku yang bahkan tidak ditata di rak. Walaupun jumlah rak sudah cukup banyak, tetapi buku tetap saja diletakkan di luar rak, hal tersebut juga karena tidak dilakukanya proses penghapusan untuk bahan koleksi sehingga banyak buku yang sudah tidak digunakan yang masih diletakkan di perpustakaan, tidak diletakkan di gudang.

Hal lain yang perlu diperhatikan dalam pengelolaan perpustakaan sekolah adalah letak perpustakaan sekolah di MTs Negeri 7 Kebumen yang berada di belakang salah satu ruang kelas dan paling pojok, apalagi ruangan perpustakaan sekolah tersebut dulunya bekas teras dan kemudian dijadikan perpustakaan sekolah, sehingga letak perpustakaan MTs Negeri 7 ini kurang strategis dan kurang nyaman bagi civitas sekolah, padahal ruang perpustakaan yang mudah diakses keberadaanya dan pengaturan tata ruang yang baik dapat membuat pemustaka menjadi nyaman.

${ }^{5}$ Anwar, Maskur, dan Jailani, Manajemen Perpustakaan. hlm.17. 
Berdasarkan observasi di atas, peneliti tertarik untuk mengetahui apakah perpustakaan pengelolaan perpustakaan MTs Negeri 7 Kebumen sudah tergolong baik atau belum, dan bagaimana penerapan sistem pengelolaan perpustakaan selama ini. Oleh karena itu, pengelolaan perpustakaan sekolah di MTs Negeri 7 Kebumen perlu dikaji agar menjadi tolak ukur bagi perpustakaan itu sendiri maupun sekolah lain atau madrasah lain untuk mengembangkan pengelolaan perpustakaan yang baik.

\section{METODE PENELITIAN}

Penelitian ini menggunakan jenis penelitian kualitatif untuk mendiskripsikan tentang pelaksanaan pengelolaan perpustakaan sekolah atau madrasah. Adapun tempat pelaksanaan penelitian ini adalah MTs Negeri 7 Kebumen yang terletak di komplek Kauman Prembun Desa Bagung Kecamatan Prembun Kabupaten Kebumen, Provinsi Jawa Tengah dari tanggal 6 April 2020 sampai dengan 6 Mei 2020.

Sumber data dari penelitian ini terbagi menjadi dua, yaitu data primer dan data sekunder. Data primer yang dimaksud adalah Kepala MTs Negeri 7 Kebumen, Kepala Perpustakaan, staf perpustakaan, dan beberapa Siswa MTs Negeri 7 Kebumen, sedangkan data sekunder penunjang penulis mengambil dari buku-buku, mengumpulkan dokumentasi dan referensi lain yang berhubungan dengan penelitian ini.

Fokus penelitian ini menekankan pada pengelolaan perpustakaan yang ada di MTs Negeri 7 Kebumen. Pengelolaan perpustakan yang akan diteliti lebih berfokus kepada pengelolaan perpustakaan, yakni perencanaan, pengorganisasian, pelaksanaan atau penggerakan, evaluasi dan kendala yang dihadapi dalam manajemen perpustakaan.

Teknik pengumpulan data yang digunakan dalam penelitian ini berupa observasi, wawancara, dan dokumentasi. Kemudian untuk menghasilkan data yang kredibel dan dapat dipertanggungjawabkan, penelitian ini menggunakan dua triangulasi, yaitu sumber dan metode:

1. Triangulasi sumber, yaitu menggunakan berbagai sumber untuk mendapatkan informasi. Pada triangulasiini peneliti tidak hanya menggunkan informasi dari satu informasi saja, tetapi informasi dari para informan di lingkungan tempat penelitian.

2. Triangulasi metode, yaitu dengan membandingkan berbagai data hasil wawancara, observasi, dan dokumentasi. Data-data yang telah diperoleh kemudian dibandingkan satu sama lainnya agar teruji kebenarannya.

Teknik analisis data dalam penelitian ini menggunakan analisis dari Miles dan Huberman yaitu data reduction, data display, dan conclusion drawing/verfication ${ }^{6}$.

\section{HASIL PENELITIAN DAN PEMBAHASAN}

\section{Pelaksanaan Pengelolaan Perpustakaan MTs Negeri 7 Kebumen}

\section{a. Perencanan}

Anwar menjelaskan bahwa perencanaan melibatkan urusan memilih tugas yang harus dilakukan untuk mempertahankan tujuan organisasi, menjelaskan bagaimana tugas harus dilaksanakan, dan memberi indikasi kapan harus dikerjakan. Aktivitas perencanaan memfokuskan pada mempertahankan tujuan. ${ }^{7}$ Sutarno menjelaskan mengenai pentingnya perencanaan bagi suatu perpustakaan, maka dalam penyusunan diperlukan pengetahuan dan pengalaman yang luas. Perencanaan merupakan dasar pelaksanaan aktivitas, perencanaan

\footnotetext{
${ }^{6}$ Sugiyono, Metode Penelitian Pendidikan Pendekatan Kuantitatif, Kualitatif, dan R\&D(Bandung: Alfabeta, 2010). hlm.335.
}

${ }^{7}$ Anwar, Maskur, dan Jailani, Manajemen Perpustakaan. hlm.5. 
merupakan alat pengawasan, dan perencanaan yang profesional akan membawa efektivitas dan efisiensi. Perencanaan perpustakaan merupakan proses yang berkaitan dengan pemilihan, penetapan metode yang mau digunakan sebagai bentuk usaha untuk mencapai tujuan yang akan dicapai oleh perpustakaan. ${ }^{8}$

Sebagaimana diketahui bahwa sebelum melakukan pengelolaan perpustakaan yang ideal, banyak yang harus disiapkan oleh beberapa pihak yang terlibat dalam pengelolaan perpustakaan, salah satunya adalah perencanaan perpustakaan. Perpustakaan MTs Negeri 7 Kebumen telah memiliki visi, misi dan tujuan dari perpustakaan, rencana perpustakaan madrasah yang tertuang dalam program kerja perpustakaan secara umum akan mengacu pada tugas pokok perpustakaan madrasah, tujuan institusi, visi dan misi madrasah. Hal ini didasari oleh kepentingan bersama untuk menciptakan suasana kegiatan belajar yang efektif dan efisien. Perpustakaan di MTs Negeri 7 Kebumen memiliki visi, misi, dan tujuan tersendiri yang masih dilaksanakan tahap demi tahap mengingat kondisinya masih sederhana.

Lasa menerangkan bahwa fungsi dari perencanaan perpustakaan adalah untuk membantu tercapainya tujuan dan tercapainya evektivitas dan efisiensi. ${ }^{9}$ Adapun tahapan dari perencanaan yaitu:

1) Penetapan visi, misi dan tujuan. Keberadaan visi dalam sebuah perpustakaan berfungsi untuk memperjelas arah perkembangan perpustakaan dan memotivasi seluruh komponen untuk mengambil tindakan ke arah yang benar. Adapun misi merupakan penjabaran visi dengan rumusan-rumusan kegiatan yang akan dilakukan yang hasilnya dapat diukur, dilihat, dirasakan maupun dibuktikan karena bersifat kasat mata, sedangkan tujuan adalah sasaran yang akan dicapai suatu perpustakaan dalam jangka yang pendek dan hasilnya bisa dirasakan.

2) Perumusan keadaan sekarang. Keadaan perpustakaan sekarang perlu dipahami, baik kekurangan maupun kelebihannya.

3) Identifikasi kemudahan dan hambatan. Kekuatan adalah segala sesuatu yang mendorong kemajuan suatu perpustakaan.

Perencanaan Perpustakaaan MTs Negeri 7 Kebumen sudah dilakukan, yakni merencanakan membangun gedung perpustakaan yang dilengkapi dengan sarana dan prasarana, menambah fasilitas untuk layanan administrasi, mengaktifkan pengelola dan siswa dalam mengakses e-perpustakaan, menambah jumlah e-book dalam e-perpustakaan, dan menambah koleksi bacaan seperti koleksi literasi dan buku mata pelajaran. Perencanaan perpustakaan tersebut sudah berjalan sedikit demi sedikit walaupun belum berjalan secara maksimal karena terhambat dengan beberapa kendala, utamanya adalah kendala ruangan perpustakaan yang masih terbatas dan kurang strategis.

\section{b. Pengorganisasian}

Pengorganisasian yakni memberi tugas sebagai hasil dari tahapan perencanaan, tugas tersebut diberikan kepada beragam individu atau grup didalam organisasi. Hasil dari pengorganisasian bukanlah dari sebuah struktur organisasi, melainkan terogranisasinya semua aktifitas di dalam suatu wadah organisasi, sehingga tugas dan fungsi berjalan guna mencapai tujuannya. Satuan organisasi yang diperlukan antara lain; kepala perpustakaan, tata usaha, bagian pengelolaan, dan bagian pelayanan ${ }^{10}$.

Tahap pengorganisasian sangat dibutuhkan dalam hal pelaksanaan pengelolaan perpustakaan karena untuk mengetahui tugas-tugas apa yang diberikan untuk melaksanakan perencanaan yang sudah ditentukan, serta dapat berjalan secara maksimal dan terstruktur. Struktur organisasi di Perpustakaan MTs Negeri 7 Kebumen sudah sesuai dengan standar dan dalam pelaksanaannya sudah berjalan sesuai dengan tugasnya masing-masing. Kalida

${ }^{8}$ Sutarno, Manajemen Perpustakaan Suatu Pendekatan Praktik(Jakarta: Sagung Seto, 2006). hlm.16.

${ }^{9}$ Hs., Manajemen Perpustakaan. hlm.56.

${ }^{10}$ B. Suryosubroto, Proses Belajar Mengajar di Sekolah: Wawasan Baru, Beberapa Metode Pendukung, dan Bebrapa Komponen Layanan Khusus (Jakart: Rineke Cipta, 2009). hlm.253. 
menjelaskan bahwa dalam kegiatan pelaksanaan pengelolaan dapat berjalan dengan baik dengan memahami beberapa prinsip pengelolaan perpustakaan sebagai berikut: 1) Pembagian kerja dan kewenangan, 2) Kepatuhan bawahan kepada pemegang kewenangan, 3) Kesatuan pemimpin, satu pemerintah untuk setiap orang, 4) Kepentingan umum organisasi diutamakan dari pada kepentingan pribadi atau kelompok, 5) Penghargaan terhadap setiap pegawai dengan adil sesuai dengan jasa dan prestasinya yang memuaskan, 6) Asas keterlibatan dalam organisasi, 7) Asas kewajaran dan keadilan, 8) Asas adanya prakarsa tumbuhnya inisiatif dari bawahan kepada atasan, 9) Asas kerukunan dalam organisasi. ${ }^{11}$

Berdasaarkan hasil pengamatan di Perpustakaan MTs Negeri 7 Kebumen, struktur organisasi sudah disusun dan terpajang dengan jelas, seperti Kepala Madrasah sebagai penanggung jawab, kemudian adanya Kepala Perpustakaan dan dua staf perpustakaan serta tugasnya masing-masing.

\section{c. Pelaksanaan}

Winardi menjelaskan mengenai fungsi dari adanya pelaksanaan untuk menggabungkan dari beberapa fungsi manajemen yang saling berhubungan satu sama lainya, yakni meliputi kepemimpinan, pengarahan, komunikasi, pemberian motivasi, dan penyediaan sarana dan prasarana atau fasilitas. ${ }^{12}$

Ada beberapa kegiatan dalam manajemen perpustakaan diantaranya:

\section{1) Manajemen Pengadaan Bahan Koleksi}

Hartono menjelaskan bahwa manajemen koleksi merupakan area kunci dari tanggung jawab seorang guru dan pustakawan. Koleksi sendiri dapat didefinisikan sebagai sebuah bahan pustaka ataupun sejenisnya yang dikumpulkan, dikelola, dan disimpan dengan kriteria tertentu. Pengelolaan koleksi yang baik akan menentukan sukses tidaknya sebuah program perpustakaan sekolah, salah satu karakteristik dari sebuah koleksi perpustakaan sekolah adalah beragamnya jenis sumber bahan pustaka, dan keberhasilan manajemen perpustakaan salah satunya tergantung pada kebutuhan pengajaran, ukuran atau jumlah koleksi. ${ }^{13}$

Pengadaan bahan koleksi dilakukan untuk mengembangkan koleksi di perpustakaan yang melalui berbagai cara, yaitu pembelian, tukar-menukar, penerimaan hadiah, maupun penerbitan sendiri oleh perpustakaan atau lembaga induknya. Fungsi dari adanya pengadaan bahan koleksi yaitu untuk melengkapi bahan-bahan pustaka yang akan dijadikan koleksi perpustakaan. Pengadaan koleksi di MTs Negeri 7 Kebumen dilakukan dengan cara pembelian sendiri, sedangkan proses tukar-menukar, penerimaan hadiah maupun penerbitan sendiri itu belum ada. Hasil analisis yang peneliti lakukan pengelolaan pengadaan koleksi yang ada di perpustakaan MTs Negeri 7 Kebumen berjalan dengan kurang maksimal terlihat dari pengadaanya dilakukan hanya dengan cara pembelian dengan sendirinya tanpa adanya bantuan dari pihak lain dan tidak adanya proses penghapusan buku. Seperti yang dikatakan oleh Hartono bahwa adanya tujuan pengadaan bahan pustaka itu sendiri untuk menghindari buku-buku atau jenis lainnya yang sebenarnya kurang bermanfaat bagi pengguna perpustakaan masuk kedalam jajaran koleksi.

\section{2) Manajemen Pengolahan Bahan Pustaka}

Darmanto menjelaskan pengolahan bahan pustaka dimaksudkan untuk mempermudah para pemustaka dalam menggunakan bahan pustaka di perpustakaan. Aktivitas pengelolaan ini ialah mengolah berbagai jenis bahan bahan pustaka yang diterima oleh perpustakaan, baik berupa buku, majalah, tabloid, koran, kamus, buletin, skripsi, tesis, manuskrip, laporan, atlas,

\footnotetext{
${ }^{11}$ Muhsin Kalida, Capacity Building Perpustakaan (Yogyakarta: Aswaja Pressindo, 2015). hlm.5.

${ }^{12}$ Winardi, Asas-asas Manajemen (Bandung: Mandar Maju, 2000). hlm.33.

${ }^{13}$ Hartono, Dasar-dasar Manajemen Perpustakaan dari Masa ke Masa (Malang: UIN-Maliki Press, 2015). hlm.22
} 
maupun penerbitan pemerintah. Fungsi dari adanya pengelolaan bahan pustaka adalah untuk menyimpan dan temu kembali informasi, baik pustakawan maupun pengguna jasa perpustakaan, harapannya agar pengguna mudah memanfaatkan bahan pustaka yang ada di perpustakaan. ${ }^{14}$ Manajemen pengolahan bahan pustaka Perpustakaan MTs Negeri 7 Kebumen dapat dilihat dari inventarisasi, klasifikasi, katalog, dan shelving. Untuk hal inventarisasi di Perpustakaan MTs Negeri 7 Kebumen sudah dilakukan secara online mengunakan aplikasi SLiMS. Begitu juga dengan proses klasifikasi dan katalogisasi sudah dilaksanakan secara online dan terdapat kartu kartalog. Bahan Pustaka juga sudah diberi stampel Perpustakaan MTs Negeri 7 Kebumen untuk menandakan kepemilikian yang identifikasi koleksi. Bahan pustaka juga sudah dilabeli dan ditata di rak dengan baik.

\section{3) Manajemen Layanan Perpustakaan}

Darmono menjelaskan bahwa pelayanan perpustakaan merupakan pekerjaan dan tugas penting dari semua kegiatan di perpustakaan. Pelayanan perpustakaan akan berlangsung selama perpustakaan itu buka. Pada dasarnya, layanan perpustakaan merupakan pemberian layanan informasi kepada para pengguna perpustakaan terkait dengan penyediaan bahan-bahan pustaka yang diperlukan oleh pengguna, baik digunakan di dalam perpustakaan maupun dipinjam. ${ }^{15}$ Layanan di Perpustakaan MTs Negeri 7 Kebumen sudah dilakukan dan dapat dikatakan pelayananya sudah cukup baik. Selain itu, untuk mengembangkan fungsi manajemen, pelaksana perpustakaan juga saling berhubungan satu sama lain dengan dilakukannya pengarahan, komunikasi dan kerjasama yang baik antar para petugas perpustakaan. Kepala perpustakaan dan para petugas perpustakaan di MTs Negeri 7 Kebumen sudah sudah melakukan pengarahan, komunikasi, dan kerjasama yang baik.

\section{d. Evaluasi}

Evaluasi merupakan proses yang sangat penting dalam kegiatan pendidikan. Menurut Dirman, evaluasi adalah pengawasan yang dilakukan dengan mengadakan pengakuan terhadap keseluruhan penyelenggaraan, terutama setelah semuanya selesai. Evaluasi semacam ini dilakukan untuk menyiapkan lagi suatu perencanaan atas semua aktivitas yang akan datang. ${ }^{16}$ Evaluasi memiliki kegunaan atau manfaat bagi semua pihak yang berkepentingan dalam proses pendidikan, terutama peserta didik, guru, sekolah, dan masyarakat. Menurut Robbins yang dimaksud dengan evaluasi adalah suatu proses memonitor aktivitas untuk mengetahui apakah individu atau organisasi itu sendiri memperoleh dan memenfaatkan sumber-sumber pendidikan secara efektif dan efisien dalam rangka mencapai tujuan. Pelaksanaan tugas dan tanggung jawab dalam suatu perpustakaan perlu adanya evaluasi agar dapat diperoleh hasil sebagaimana yang diharapkan dan untuk memperoleh peningkatan kualitas. ${ }^{17}$

Adapun prosedur evaluasi yang dilakukan Kepala Madrasah di MTs Negeri 7 Kebumen sebagai evaluator yaitu perpustakaan membuat laporan tahunan dan komunikasi pribadi secara langsung dengan mengunjungi perpustakaan. Hasil analisis pelaksanaan evaluasi di perpustakan MTs Negeri 7 Kebumen sudah dilakukan dengan baik. Hal ini dapat dilihat dari adanya laporan tahunan dan evaluasi terhadap kepala perpustakaan dan staf perpustakaan. Kepala perpustakaan dan para staf perpustakaan selalu bertemu setiap hari dan apabila ada masalah yang berhubungan dengan perpustakaan selalu segera dibicarakan.

\footnotetext{
${ }^{14}$ Darmanto, Manajemen Perpustakaan. hlm.33.

${ }^{15}$ Darmono, Perpustakaan Sekolah: Pendekatan Aspek Manajemen dan TataKerja. hlm.115. 2014). hlm.2

${ }^{6}$ Dirman, Penilaian dan Evaluasi: Dalam Rangka Implementasi Standar Proses Pendidikan Siswa (Jakarta: Rineke Cipta,

${ }^{17}$ Stephen P. Robbins, Organizational Behavior(New Jersey: Prentice Hall, 2003).
} 


\section{Kendala Pengelolaan Perpustakaan MTs Negeri 7 Kebumen}

Pada umumnya perpustakaan sekolah memiliki hambatan untuk mengelola sebuah perpustakaan, sehingga perpustakaan belum bisa berjalan sebagaimana mestinya. Hambatan tersebut bisa berasal dari dua aspek. Pertama, aspek setruktural, dalam arti keberadaan perpustakaan sekolah kurang memperoleh perhatian dari pihak manajemen sekolah. Kedua, aspek teknis artinya aspek persifat teknis yang sangat dibutuhkan oleh perpustakaan sekolah seperti tenaga, dana, serta sarana dan prasarana.

Menurut Darmono ada beberapa kendala yang dialami sekolah dalam melaksanakan pengelolaan perpustakaan sekolah atau madrasah sebagai berikut: a) Minimnya dana operasional untuk perpustakaan sekolah. Secara umum, dana menjadi persoalan hampir di semua instansi, b) Minat baca siswa yang masih belum menggembirakaan, walaupun pemerintah telah mencanangkan berbagai program tentang minat baca, c) Terbatasnya sumber daya manusia yang mampu mengelola perpustakaan sekolah serta mempunyai visi pengembangan yang baik, d) Kepedulian pihak manajemen sekolah terhadap pengembangan perpustakaan masih rendah, e) Masih terbatasnya sarana dan prasarana yang dibutuhkan untuk menunjang keberadaan perpustakaan sekolah, f) Kebijakan pemerintah dalam hal ini Departemen Pendidikan Nasional tentang perpustakaan sekolah belum manjadi titik perhatian. Perpustakaan sekolah masih dianggap sebagai sarana perlengkap untuk kegiatan belajar siswa dan bukan sebagai jantung sekolah untuk menggerakan proses kegiatan belajar, g) Belum adanya kebijakan nyata dalam kurikulum tentang jam khusus bagi murid untuk berbagi kegiatan pemanfaatan dan atau kegiatan di perpustakan sekolah, karena tidak adanya jam khusus penggunaan perpustakaan yang terintegrasi dengan kurikulum, sehingga fungsi perpustakaan sekolah hanya sebagai bursa peminjaman buku bagi siswa pada jam istirahat sekolah. Siswa tidak pernah punya waktu untuk berlama-lama di perpustakaan sekolah karena memang tidak ada alokasi waktu secara khusus untuk memanfaatkan bahkan hanya berkunjung ke perpustakaan. ${ }^{18}$

Kendala yang dihadapi di perpustakaan MTs Negeri 7 Kebumen ada dua hal, yaitu keterbatasan ruangan dan tidak ada pelatihan khusus bagi staf perpustakaan, sehingga dalam proses pengelolaan perpustakaan tidak berjalan secara maksimal.

\section{SIMPULAN}

Berdasarkan uraian pembahasan di atas, penelitian ini dapat disimpulkan sebagai berikut: 1. Pengelolaan perpustakaaan sekolah di MTs Negeri 7 Kebumen sudah dilaksanakan cukup baik. Hal ini dapat dilihat dari hasil pengamatan dari segi perencanaanya yang sangat banyak dan sudah dibuat, misalnya merencanakan membangun gedung perpustakaan yang lengkap fasilitasnya, menambah fasilitas untuk layanan administrasi, mengaktifkan pengelola dan siswa dalam mengakses e-perpustakaan, menambah jumlah e-book dalam e-perpustakaan, dan menambah koleksi bacaan literasi dan buku mata pelajaran. Dalam hal perencanaan sudah berjalan sedikit demi sedikit walaupun belum berjalan maksimal karena terhambat dengan beberapa kendala, dan kendala yang paling utama itu adalah pada ruangan perpustakaan.

2. Pengorganisasaian pengelolaan perpustakaan sudah berjalan secara terstruktur dan memenuhi standar. Hal ini dapat dilihat dari hasil pengamatan yang terdapat struktur organisasi seperti Kepala Madrasah sebagai penanggung jawab, kemudian adanya Kepala Perpustakaan dan dua staf perpustakaan serta tugasnya masing-masing.

3. Pelaksanaan Pengelolaan Perpustakaan sudah berjalan dengan cukup baik dilihat dari segi pengamatan adanya pengadaan koleksi, pengelolaan bahan koleksi dan pelayanan perpustakaan. Pengadaan koleksi sudah berjalan cukup baik walaupun proses pengadaanya

\footnotetext{
${ }^{18}$ Darmono, Perpustakaan Sekolah: Pendekatan Aspek Manajemen dan TataKerja. hlm.30.
} 
masih dilakukan dengan beli sendiri menggunakan uang dari denda siswa. tetapi ada beberapa kendala yang menghambat proses pengadaan koleksi, seperti kebutuhan buku yang sudah tidak dijual kembali, serta tidak ada proses penghapusan koleksi, sehingga mengakibatkan banyak buku di perpustakaan yang sudah tidak digunakan lagi. Pengelolaan bahan pustaka dilakukan dengan baik. Hal ini dapat diamati dari adanya inventarisasi, klasifikasi, katalogisasi, dan sirkulasi yang sudah dilakukan secara online. Tetapi dalam hal shelving, perpustakaan belum melakukan secara maksimal. Hal ini dapat dilihat dari banyaknya buku yang tidak ditata di rak dan penataanya tidak sesuai dengan klasifikasinya. Dalam hal pelayanan juga cukup baik, dilihat dari proses peminjaman dan pengembalian buku sudah dilakukan secara online dan siswa juga memiliki kartu tersendiri untuk proses peminjaman dan pengembalian buku, walaupun peminjaman buku pelajaran atau paket masih menggunakan sistem manual.

4. Evaluasi pelaksanakan pengelolaan perpustakaan sudah baik, dilihat dari pengamatan bahwa evaluasi dilakukan setiap hari karena sering bertemu, dan setiap tahun sekali membuat laporan tahunan yang nantinya akan diteliti oleh Kepala Madrasah.

5. Kendala yang dihadapi dalam pengelolaan perpustakaan adalah mengenai ruangan yang tidak memenuhi standar, sarana dan prasarananya kurang mencukupi, pengadaan bahan koleksi kurang maksimal, dan tidak ada pelatihan khusus bagi staf perpustakaan.

\section{DAFTAR PUSTAKA}

Anwar, Sudirman, Said Maskur, dan Muhammad Jailani. Manajemen Perpustakaan. Riau: Indragiri, 2019.

Darmanto, Priyono. Manajemen Perpustakaan. Jakarta: Bumi Aksara, 2018.

Darmono. Perpustakaan Sekolah: Pendekatan Aspek Manajemen dan TataKerja. Jakarta: Grasindo, 2001.

Dirman. Penilaian dan Evaluasi: Dalam Rangka Implementasi Standar Proses Pendidikan Siswa. Jakarta: Rineke Cipta, 2014.

Hartono. Dasar-dasar Manajemen Perpustakaan dari Masa ke Masa. Malang: UIN-Maliki Press, 2015.

Hs., Lasa. Manajemen Perpustakaan. Yogyakarta: Pinus, 2009.

Kalida, Muhsin. Capacity Building Perpustakaan. Yogyakarta: Aswaja Pressindo, 2015.

Robbins, Stephen P. Organizational Behavior. New Jersey: Prentice Hall, 2003.

Sugiyono. Metode Penelitian Pendidikan Pendekatan Kuantitatif, Kualitatif, dan R\&D. Bandung: Alfabeta, 2010.

Suryosubroto, B. Proses Belajar Mengajar di Sekolah: Wawasan Baru, Beberapa Metode

Pendukung, dan Bebrapa Komponen Layanan Khusus. Jakart: Rineke Cipta, 2009.

Sutarno. Manajemen Perpustakaan Suatu Pendekatan Praktik. Jakarta: Sagung Seto, 2006.

Winardi. Asas-asas Manajemen. Bandung: Mandar Maju, 2000. 